\title{
Cross-sensory experiences and the enlightenment: music synesthesia in context
}

\author{
Eduardo Sola Chagas Lima (Burman University, Lacombe, Alberta, Canada)
} eduardosola@burmanu.ca

\begin{abstract}
This study contemplates cross-sensory experiences as represented in late eighteenth-century thought, prior to George Sachs's description of synesthesia in 1812. Sachs's medical dissertation is now considered to be the first convincing scientific report of synesthesia in literature. Yet, less objective historical instances of crosssensory experiences are not new to music, the visual arts, and poetry. Since these instances are difficult to assess on the part of modern disciplines (including musicology) due to their subjective nature, references to cross-sensory experiences prior to this date are either overlooked or simply ignored. The Medieval and Renaissance understandings of multisensory associations, deriving from natural science and cosmology, gradually gave way to rationalized discussions based on mathematics, physics, and practical experimentations as time elapsed. In eighteenth-century literature, allusions to sound-colour parallels enjoy special attention in the writings of Voltaire, Rousseau, Diderot, among others. In discussing the validity of these associations and their mechanisms, some authors extended these correspondences to other senses as well: touch, taste, and smell. This research is rooted in a historical survey of Enlightenment approaches to multisensory experiences-along with their priority for reason-discussing to which extent they are strictly 'scientific,' since the long eighteenth century still witnessed the coexistence of natural, cosmological, and philosophical readings of cross-sensory analogies. It also inquires whether Enlightenment thought established a philosophical foundation for initial investigations on music synesthesia. Finally, this study searches for a place for Sachs's dissertation among Enlightenment debates-the philosophical and historical context that afforded its conception.
\end{abstract}

Keywords: Music synesthesia. Enlightenment. Cross-sensory experiences. Multisensory experiences.

\section{Experiências multissensoriais e o iluminismo: sinestesia musical em contexto}

Resumo: Este estudo contempla experiências multissensoriais tais quais representadas no pensamento do final do século XVIII, anteriores à descrição de sinestesia por George Sachs em 1812. A dissertação médica de Sachs é considerada o primeiro relatório científico convincente de sinestesia na literatura. No entanto, instâncias históricas menos objetivas de experiências multissensoriais não são novas na música, artes visuais e poesia. Como essas instâncias são difíceis de avaliar por parte das disciplinas modernas (incluindo a musicologia) devido à sua natureza subjetiva, referências a experiências multissensoriais anteriores a essa data são negligenciadas ou simplesmente ignoradas. As leituras medievais e renascentistas de associações multissensoriais, derivadas da ciência natural e da cosmologia, gradualmente deram lugar a discussões racionalizadas baseadas na matemática, física e experimentações práticas com o passar do tempo. Na literatura do século XVIII, alusões a paralelismos entre cor e som ganham atenção especial em Voltaire, Rousseau, Diderot, entre outros. Ao discutir a validade dessas associações e seus mecanismos, alguns autores estenderam essas correspondências também a outros sentidos: tato, paladar e olfato. A presente pesquisa oferece um levantamento histórico das abordagens iluministas às experiências multissensoriais-juntamente com sua prioridade pela razão—discutindo até que ponto estas são estritamente "científicas", uma vez que século XVIII testemunhou a coexistência de leituras naturais, cosmológicas e filosóficas de analogias intersensoriais. Também indaga-se se o pensamento iluminista estabeleceu um fundamento filosófico para as investigações iniciais sobre a sinestesia musical. Finalmente, este estudo procura contextualizar descrição de sinestesia por Sachs entre os debates iluministas—o contexto filosófico e histórico que proporcionou sua concepção.

Palavras-chave: Sinestesia musical. Iluminismo. Experiências multissensoriais.

\section{Introduction}

Multisensory associations, though a prominent topic in Enlightenment discussions, are not exclusive to eighteenth-century philosophy. They have permeated literature since ancient Greece and also found their way into musical thought throughout history, often in the specific relation between tone (sound) and colour. As far as sound-image analogies are concerned, the seventeenth and eighteenth centuries witnessed an evolution in musical thought, from magical readings inherited from medieval cosmology, to philosophical and scientific attempts to rationally explain connections between them. These attempts are 
recorded in the form of theoretical propositions, practical experiments, philosophical reasoning, or pure logic. Yet, these epistemological frameworks, far from being distinctive and historically consecutive, coexisted and informed one another during the long eighteenth century and the inherited medieval approach to the natural world only gradually and with difficulty gave way to new perspectives and possibilities.

These coexisting epistemological streams characteristic of the Enlightenment still permeate modern approaches to the subject of multisensory association to a certain extent. In fact, some of the tables and lists showing cross-sensory connections in early documents still find analogous representations in current literature, thus showing that in many respects extant research remains similar to those sources. Examples of lists of cross-sensory correspondences can be found in recent publications, such as the well-known books by Jamie Ward (2008) and Richard Cytowic (2009). Hence, the reality that these traces of inherited knowledge are still present in current research on synesthesia raises questions as to what exactly a strictly 'scientific' approach entails-since in their own context, approaches to cross-sensory experience have been somewhat 'scientific' all along. In this sense, because modern research on synesthesia both retained inherited epistemology at the same time as it made considerable advancements and matured as a sub-discipline, the extent to which current methods are expressly scientific is fairly relative.

In this research I analyze the transformation of scientific approaches to crosssensory experience in light of their historical and philosophical contexts. I also explore some of the visual and sonic aspects within reported cases of multisensory experience described in early primary sources. Furthermore, rather than focusing on the music-sound association alone, I propose that the very relationship between tone and colour may be better understood in terms of the various eighteenth-century perspectives on cross-sensory experience in general. Thus, as the title of this paper suggests, I look at various eighteenthcentury sources in search of a place for what is currently understood as 'music synesthesia,' visiting the propositions of natural philosophers and their noteworthy experiments, such as the polemic 'ocular harpsichord'. I finally consider the first account of music synesthesia of 1812 and how it interacts with its contemporary currents of thought. In so doing, I hope to present music-sound analogies in a holistic historical perspective.

\section{First report of synesthesia}

Synesthesia is currently defined as an abnormal neurological condition (ASHER et al., 2013, p. 23), characterized by superabundant connectivity between areas of the brain that normally become separated and specialized throughout brain development. This phenomenon is usually associated with a connection between the senses, although correspondences between different brain areas are not limited to the regions of the brain responsible for sensorial functions. In fact, synesthesia is now understood to potentially entail connections between areas of the brain that may be not "sensorial" (CITOWYC, 2009, p. 237), so to speak, such as the regions responsible for problem solving, organization, and planning, to name a few examples. Nonetheless, the present study is concerned specifically with connections between the senses, since the discovery of synesthesia in the early nineteenth-century is closely linked to cross-sensory correspondences. Non-sensory connections, on the other hand, are to a large extent still left for future research to explore. Besides, the 'union' or 'joining of the senses,' as the term synesthesia translates into English and is commonly referred to in literature, is also the form of the condition that is easiest to assess and phenomenologically disentangle-which explains its prominence in research as the most well documented type of cross-sensory perception. 
In a nutshell, the perceptual phenomenon of synesthesia is defined in terms of an inducing stimulus and a concurrent synesthetic sensation. The perceived inducer triggers an automatic synesthetic response. For example, in grapheme-colour synesthesia the perception of the letter "E" may trigger the colour blue. The same relationship is valid for music. In musical note-colour synesthesia a given pitch, or concept of a musical note, may induce a concurrent sensation of colour at a neurological level. Sound-colour associations (as in other types of colour synesthesia) are automatic, involuntary, consistent over time, and real (WARD, 2008). They are also independent from rationalized analogies, in the sense that no two synesthetes will agree on their correspondences. Thus, some of the main requirements for a diagnosis of synesthesia are individuality, automaticity, consistency, reality, and an involuntary basis.

George Tobias Ludwig Sachs is responsible for what is now considered to be the first scientific account of synesthesia in medical literature. He published his work in 1812 in form of a medical dissertation at the University of Erlangen, Germany. Not only had he grapheme-colour synesthesia-until today the most prevalent and most commonly studied mode of the condition; he also experienced concurrent colours when exposed to musical sounds (JEWANSKI et al., 2009, p. 297). Sachs's report is currently regarded as the cornerstone for later developments in the study of multisensory experience.

Research on synesthesia has come a long way since the 1812 account. The condition evolved from questionable scientific evidence (or mere curiosity) to an arguable, documented neurological condition. It also often figures in the title of scholarly publications and academic gatherings in psychology and neuroscience. But what to make of synesthesia before this first account? If there are potential reported cases of synesthesia prior to 1812, why are they ignored in medical literature? Most importantly, what is the historical significance of potential cases of synesthesia for the discussion of cross-sensory experiences in the Enlightenment?

The recent publication of The Oxford Handbook of Synesthesia (SIMNER et al., 2013) contemplates historical perspectives in research and also exposes facets that are still wanting in the field. One of the most salient problems with implications for the historical study of synesthesia is that current research mainly (if not solely) revolves around medical literature. In discussing the early nineteenth-century as the period entailing the "scientific origins" of the phenomenon, Jörg Jewanski et al. (2013, p. 269) state: "I focus particularly [on] cases of synesthesia reported within the scientific and medical literature, rather than potential cases within music, visual arts, and poetry. These latter are difficult to disentangle from symbolic and metaphorical movements during this period (i.e. late eighteenth and early nineteenth centuries)". Hence, although it is not surprising that quantifiable research on synesthesia would gain prominence in research today, it is paramount to consider the philosophical context in which the first account in medical literature came into being. The philosophical and social contexts that both preceded and informed the first satisfactory report of synesthesia at the time are often overlooked in literature. The inevitable outcome is that synesthesia is almost invariably considered to exist as a condition only from 1812, which is very unlikely and "there is no reason why there should not be many cases of synesthesia before [1812]” (JEWANSKI et al, 2013, p. 270).

Following its scientific rise during the nineteenth-century, synesthesia sunk into oblivion after the advent of behaviourist psychology, remaining an obscure subject from the 1930s to the 1980s. Recent approaches, however, often pertaining to analyses of the practice of experience and phenomenology, have regained the interest of psychologists and neuroscientists. These approaches are almost invariably employed in conjunction with 
more palpable evidence, such as functional magnetic resonance imaging (fMRI) scans, Stroop task tests, and other objective methods for data collection. Some of these methods, however, allow for a more subjective evaluation of perceptual experience, thus making it possible to revisit some of the "symbolic and metaphorical" cases at first rejected in Jewanski's (2009, p. 269) article; and it is also with this in mind that I would like to consider cross-sensory experiences prior to Sachs's account.

\section{Three potential cases of synesthesia before 1812}

In this essay I look at three examples of cross-sensory perception prior to George Sachs's dissertation. The main reason why none of these are accounted for as convincing scientific records of synesthesia, is due to the fact that Sachs is the first to include aspects in his methodology that are fundamental to how the condition is assessed today, such as consistency and specificity of synesthetic colour. Yet, discussing these earlier cases in light of their own philosophical and epistemological contexts allows for a better understanding of how readings of cross-sensory experience evolved during the eighteenth-century and set the stage for Sachs's revolutionary medical work. Interestingly, these cases share several similarities. All three accounts involve a blind subject and entail the relationship between colour and touch (among other analogous characteristics), which has raised questions in literature as to the validity of their content-either the three accounts address the same individual (JEWANSKI et al., 2013, p. 295) or no one in particular.

\section{Robert Boyle (1664)}

The first is reported by the Irish natural philosopher Robert Boyle in 1664, who claims a blind man from Maastricht, The Netherlands, could "see" the colours of different ribbons upon touching them (JEWANSKI et al., 2013, 294). He had become blind at the age of two due to small pox. His report suggests that there might be a relation between sensually distinct qualities in his perception. As absurd as this account may come across today, it is important to consider the epistemological framework in which it takes place. Eighteen years before this account, Athanasius Kircher remarked on the divine proportions that permeate all nature, music included (JEWANSKI, 1999, p. 198). His work was clearly influenced by Marin Mersenne's Harmonie universelle (1637). In both his Musurgia universalis (1650) and Ars magna lucis et umbrae (1646), Kircher offers parallels between colours and musical intervals, intensity of light, natural elements such as water and fire, and other sensually perceived qualities. The following table (figure 1), available in Jewanski's (1999, p. 200) book on tone-colour relations, summaries Kircher's associations:

Fig. 1. Summary of Athanasius Kircher's cross-sensory correspondences in Ars magna lucis et umbrae (1646).

\begin{tabular}{|l|l|l|l|l|l|}
\hline Colours & White & Yellow & Red & Blue & Black \\
\hline Light intensity & Light & Darkened light & Coloured light & Shadow & Darkness \\
\hline Brightness & Bright & Faint shadow & Moderate shade & Stronger Shade & Darkness \\
\hline Tastes & Sweet & Moderately sweet & Bittersweet & Sharp (like vinegar) & Bitterness \\
\hline Elements & Fire & Ether & Air & Water & Earth \\
\hline Age & Childhood & Youth & Early adulthood & Late adulthood & Old age \\
\hline Wisdom & Insight & Opinion & Error & $\begin{array}{l}\text { Obstinate } \\
\text { persistence in error }\end{array}$ & Ignorance \\
\hline States of being & God & Angels & Men & Animals & Plants \\
\hline Tones & Nete & Paranete & Mese & Paramese & Hypathe \\
\hline
\end{tabular}


Within its epistemological framework, this was considered a scientific approach to the overall harmony of the world and how different phenomena are essentially connected. In other portions of his work, he offers several purely scientific explanations, such as detailed engravings of the anatomy of the ear and the throat, although they are now regarded as archaic and inaccurate. His correspondences between sound and various other phenomena, on the other hand, would permeate eighteenth-century thought to a great extent and, as I have suggested in the introduction to this paper, still inform recent approaches.

Yet, the obsession to find a scientific parallel between the sensually distinct attributes of colour and sound would not be fully expressed until Sir Isaac Newton's propositions were published, where he suggests relationships between harmonic ratios and the colour spectrum. In a letter from 1675, Newton states:

As the harmony \& discord of Sounds proceed from the proportions of the aereall vibrations; so may the harmony of some colours, as of Golden \& blew, \& the discord of others as of red \& blew proceed from the proportions of the aethereall. And possibly colour may be distinguisht into its principal Degrees, Red, Orange, Yellow, Green, Blew, Indigo, and deep violet, on the same ground, that Sound within an eighth is graduated into tones. (NEWTON, 1959).

In Newton's proposition, the semantic associations characteristic of cosmological approaches-until then the general norm in literature-give way to a rational explanation rooted in mathematics and physics. As Emily Dolan (2013, p. 24) points out, Newton's argument was only a more rigorous scientific version of a millenary analogy, dating back to Aristotle. The very scientific 'rigour' found in Newton's work would help perpetuate soundcolour correspondences in the still largely Cartesian and reductionist Western world that would come to one of its philosophical peaks during the eighteenth century by means of the establishment of Enlightenment ideals.

As far as synesthesia goes, however, what is at stake in Boyle's report clearly is not a case of synesthetic experience. Synesthetic tone-colour relationships change from individual to individual and do not follow any 'scientifically logical' pattern. Rather, the man was said to see the real colour of the ribbons upon touching them. Hence, unless he could distinguish between textural differences in seventeenth-century dye (JEWANSKI et al., 2009, p. 294), there is no argumentative basis either at the time or at present in support of this claim's veracity or its qualification as a case of synesthesia.

\section{John Locke (1690)}

The second account was noted in 1690 by English philosopher John Locke, one of the main proponents of Enlightenment thought. Locke reports the case of a possibly congenitally blind man attests to the real "meaning" of scarlet, which he goes on to describe as "the sound of a trumpet" (JEWANSKI et al., 2009, p. 294). This is likely the most wellknown account to-date of musical cross-sensory perception prior to 1812. In discussing this case, Locke explores the objective implications of this account by referencing Molyneux's Question (or Molyneux's Problem): “if a man born blind can feel the differences between shapes such as spheres and cubes, could he similarly distinguish those objects by sight if given the ability to see?” (JEWANSKI et al., 2009, p. 295) Locke argues that a congenitally blind individual-because he/she has never seen the colour scarlet (or anything else for that matter) - is therefore unable to experience the visual attributes of that colour.

Regardless of its validity, or lack thereof, this case offers a perspective on soundcolour cross-sensory experience from a proto-Enlightenment philosophical standpoint. 
Voltaire (1738, p. 63), in his Elements of Newton's Philosophy from 1738, recounts Locke's answer to Molyneux's question, reiterating that visual qualities would by no means be recognizable to a congenitally blind man if he were to receive his sight. Hence, for both Locke and Voltaire, the sound of a trumpet could not have been red for that individual because the very concept or idea of colour would not be available to him/her, in the first place. Hence, this case also fails to qualify as synesthetic.

\section{Thomas Woolhouse (1726)}

The third case-probably of most interest presently-was allegedly reported by Thomas Woolhouse, an English ophthalmologist (JEWANSKI et al., 2009, p. 295). It is notorious because it interestingly connects to Louis-Bertrand Castel's famous clavecin oculaire, or 'ocular harpsichord.' This account is referenced in a letter from 1726 sent by Rondet, in support of the building of an ocular harpsichord, so that, as Castel (1725, p. 2553) puts it, the deaf could "enjoy the beauty of music with his eyes, [and] a blind person the beauty of colors with his ears.” This case curiously resembles both Boyle's and Locke's cases mentioned above, suggesting that they indeed could have been virtually about the same individual. It reads:

Woolhouse told me many times that he had seen in Maastricht a blind man who distinguished colours by touch. He was the son of a haberdasher who has lost his sight at the age of 6 . When one gave to this man a red cloth, he said, upon touch, that this color gives him the same effect as the sound of a trumpet or a drum. He recognized black because it was rough. As for white, or yellow, he only said that it was one or the other. It would be the same with green and blue, apparently because of the correspondence between these colors. (RONDET apud JEWANSKI et al., 2009, p. 295).

Once again, the experience recounted in this passage fails to qualify as synesthetic per se, in that it involves the real colour of the textiles. What is noteworthy in this specific instance, nevertheless, is its connection to Castel's polemic idea of potential multisensory connections. The quest to find parallels between the senses was far from over. This idea of multisensory connections would become the subject of much subsequent philosophical discussion; and one whose idiosyncrasies I now set out to explore in more detail.

\section{The ocular harpsichord and a mixing of the senses}

Castel's analogies between colour and sound, as demonstrated in the form of theoretical propositions, clearly attest to the influences of Kircher and Newton (FRANSSEN, 1991, p. 22). According to Voltaire, Newton read and was influenced by Kircher and his tone-colour analogies (HANKINS, 1994, p. 144). Voltaire praises Kircher as one of the great mathematicians of his time, and in referring to Kircher's and Newton's tone-colour correspondences, he says: "this secret analogy between light and sound leads one to suspect that all things in nature have hidden connections, that perhaps will be discovered some day" (VOLTAIRE apud HANKINS, 1994, p. 144). This is an example of the aforementioned coexistence of cosmological associations and science-based data characteristic of natural philosophy in these early sound-colour experiments. Newton, in turn, influenced Castel, who, with his harpsichord project, attempted to take multisensory analogies to the next level-a practical application. Beyond the visual attributes and potential of his ocular harpsichord, Castel had further and even more ambitious purposes for his keyboard. According to him, his harpsichord was to be the "universal instrument for the senses" 
(CASTEL apud HANKINS, 1994, p. 143). The following quotation exemplifies Castel's ultimate, ideal project:

Take some forty scent bottles filled with different perfumes, cover them with valves,
and arrange them so that the pressing of the keys open these valves: there you are
for the nose. On a board arrange objects that can make different impressions on the
hand, and then let the hand come down on each of them: there you are for the touch.
Arrange likewise some objects that taste fine, interspersed with bitter objects. But I am
talking to people who have to be told everything. (CASTEL apud FRANSSEN, 1991,
p. 22).

As Franssen (1991, p. 22) suggests, besides the visual manifestation of musical sound, Castel proposes that "there could also be a music of flavours, a music of scents and a music of touches." Dolan (2013, p. 36) to these as "metaphorical harpsichords," however, arguing that unlike the ocular harpsichord these would have been merely figurative examples of the potential of this project in connecting the senses, rather than actual propositions.

Voltaire, Rousseau, and the music theorist Heinrich Christoph Koch ridiculed Castel's 'farfetched' idea and his failed attempt to build an apparatus that portrays connections between sounds and colours. Castel himself admits "that the analogy between tones and colours was not perfect. A tone is in practice a fleeting thing, while a colour is something permanent. Moreover, in a musical piece the different tones merge into one whole, while in a painting the different colours stay clearly separated." (CASTEL apud FRANSSEN, 1991, p. 20). Rousseau suggests in his Essay on the Origins of Language that "it would be a complete misunderstanding of the workings of nature not to see that the effect of colors is in their stability and that of sounds in their succession." (ROUSSEAU apud STRUNK, 1965, p. 952). Rousseau approaches the issue in a chapter titled "False Analogy Between Colours and Sounds" and is categorical in opposing the purposes of the ocular harpsichord. In addressing the 'senses,' he argues: "each sense has its proper domain. The domain of music is time; that of painting is space. To multiply the sounds heard at a given time, or to present colors in sequence, is to alter their economy, putting the eye in the place of the ear, and the ear in the place of the eye" (ROUSSEAU apud STRUNK, 1965, p. 952). Hence, for Rousseau, the senses cannot be connected; rather, they have their own separate domain. Denis Diderot, in turn, was among the philosophers who supported Castel's project. In his writings, Diderot was interested in the formation of the senses and this might have been the reason why he took Castel's instrument seriously (HANKINS, 1994, p. 146). Diderot considered the colours in the ocular harpsichord to be a form of speech, of communication. Yet, the dual ability of Castel's harpsichord to communicate musical attributes both visually and aurally were still subject to debate. On one hand, the curiosity about connections between sensory percepts remains a reasonable priority in European philosophy; on the other, its possibility is dismissed as a ridiculous hypothesis.

As far as a repertoire for the ocular harpsichord is concerned, there is no surviving evidence of music that was written specifically for it. Castel (1725, p. 2552) generalizes the adequate repertoire to "all sorts of musical pieces" in a letter related in the periodical Mercure de France. It is likely, however, that contemporary French keyboard repertoire, such as the second and third volumes of Rameau's Pièces de Clavecin (1724 and 1726/7), would have been potential candidates among the pieces performed on the instrument. The ocular harpsichord also earned admiration by George Philipp Telemann during his stay in Paris (1737-1738), who reported it upon returning to Germany (DOLAN, 2013, p. 38), although none of his keyboard works appear to have been expressly written for the 
instrument. In any case, for Telemann, the effectiveness of Castel's harpsichord lied in its ability to convey through colour and light the same combinations and arrangements that the musical discourse affords through sounds (DOLAN, 2013, p. 38).

Telemann's perspective is especially worth unpacking because, unlike his contemporaries, he did not advocate for a natural connection between sound waves and light waves, as did Castel and others. Neither did Telemann refute that very idea, as he seemed to be concerned with something else: the harpsichord's ability to intellectually communicate music's harmonic combinations-perhaps along the same lines as Diderot. For Telemann, a deaf individual would be able to enjoy music's harmony, sequences and order by beholding how colours are combined together or succeed one another in specific patterns. He says in his report:

The tones please only through a clear distinctness, through agreement and analogy. The colours are just as varied as the tones, and have certain agreements. The eye can join them together, develop their analogies and experience their order and disorder. This experience causes the delight and stimulus in all things, and the real delight of music consists in perceiving such differences immediately or repeatedly during a short time. (...) In short: there is no doubt that this play of colours will please. For music is nothing but pleasure. (TELEMANN apud FRANSSEN, 1991, p. 28).

The intrinsic correspondences favoured by Newton and Castel are not in the least relevant for Telemann; instead, "the beauty is in the beholder's eyes," and his/her own learned associations. In this sense, the communicated musical message depends more on how colours combine to reproduce sound relations and, just as importantly, how they are perceived by the beholder; rather than what colour is connected to which musical note. It seems that the deaf 'listener' only needed to know what the colours were in order to enjoy the music. In other words, Telemann suggests that the enjoyment of the musical discourse would only be possible through sight if, and only if, its characteristic aural relations were learned visually by means of a deliberately constructed code of colours that translates that discourse.

Castel's harpsichord was for years considered to be an instrument of the imagination. Among attempts to project Castel's idea is Johannes Gottlob Krüger's (1743, p. 354) prototype of the harpsichord (shown in figure 2). In this model, the various colour projections arising from pressing different keys are concentric. The colourful 'music for the eyes' takes place in a localized point on a wall or sheet; much like a modern cinema screen. In sharing the same focal point, it is likely that the resulting projection of an A major chord, for example, would have been the combination of the independent colours for A, C-sharp, and E (FRANSSEN, 1991, p. 25). If played simultaneously, the chord might no longer have been recognizable when it comes to its individual pitches and their corresponding specific colours. Rather, the colours of different pitches within harmonic intervals or chords would combine into a blended mixture.

It follows that, in this prototype the pitches A, C-sharp and E in the A major harmony would result in a specific shade when played simultaneously. Unless that specific shade was known to the beholder to be A major, it would be very difficult to identify that combination as such and as distinct from another combination of notes. To make it even more complex: if any of the notes in a chord were doubled, the resulting shade would be also altered. Consider the opening bars of "Les Rappel des Oiseaux" from the aforementioned Pièces de Clavecin (1724) by Rameau as an example (figure 3). The specific colours connected with notes E, G and B-combining rather haphazardly to constitute the 
E minor harmony in the opening bars-would be recurrent for five consecutive measures and fairly easy to recognize by means of learned colour associations. Harmonic variety in other passages (figure 4) would result in likewise varied colour displays that might have been far too complex to in terms of their sound correspondence in order to be appreciated as music.

Fig. 2. Krüger's (1743) prototype of the ocular harpsichord, featuring a concentric colour projection.

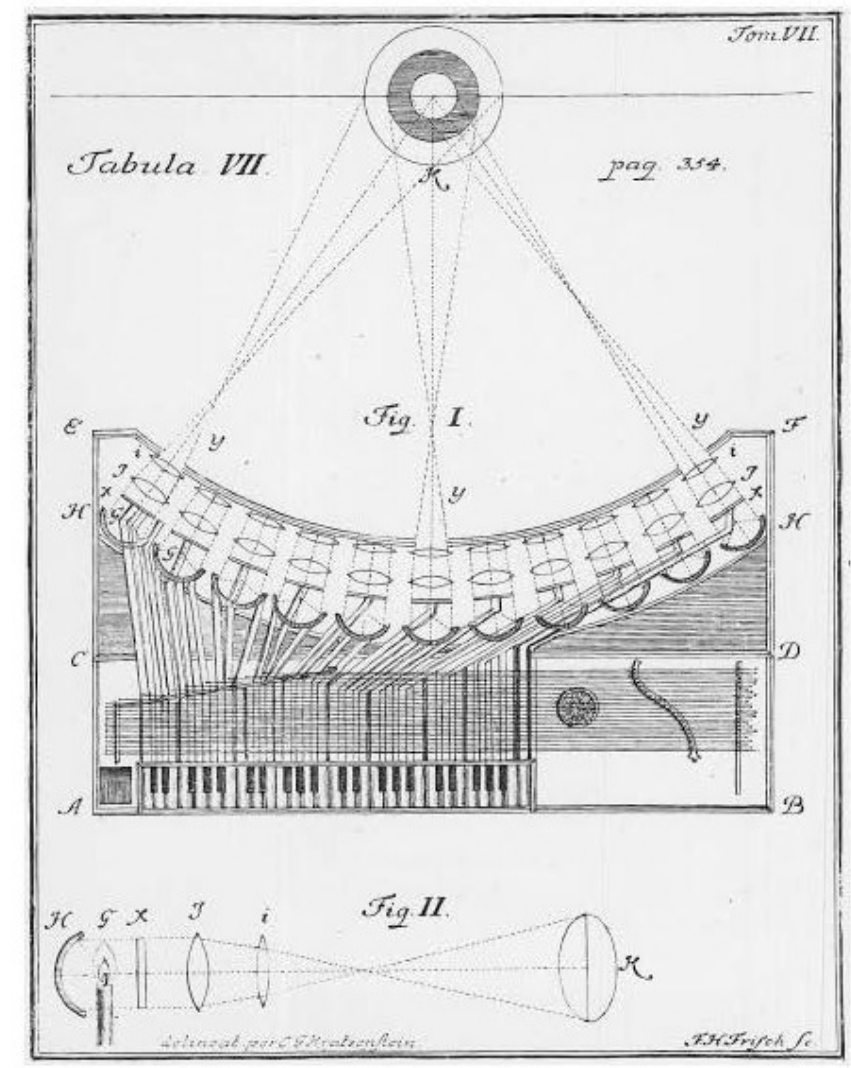

Fig. 3. Rameau, “Les Rappel des Oiseaux," Pièces de Clavecin, mm. 1-5.

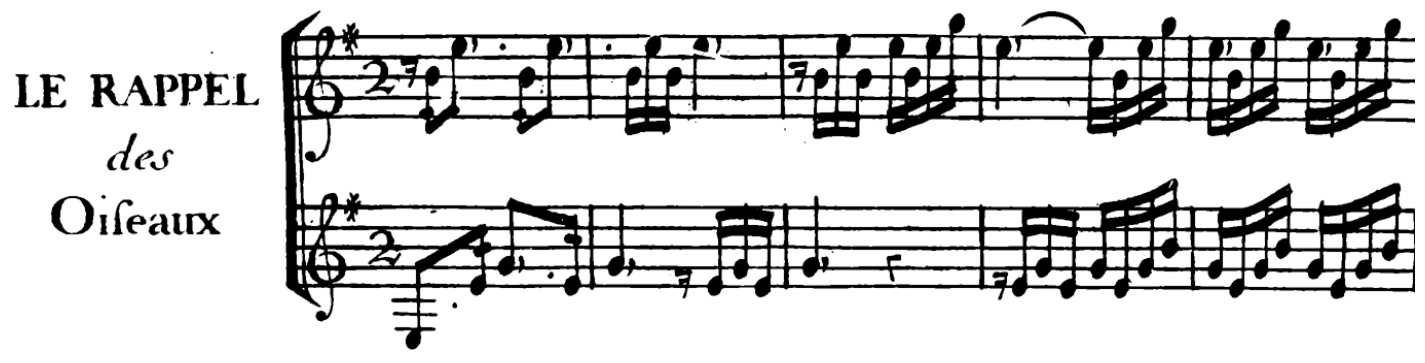

Fig. 4. Rameau, "Les Rappel des Oiseaux," Pièces de Clavecin, mm. 33-36.

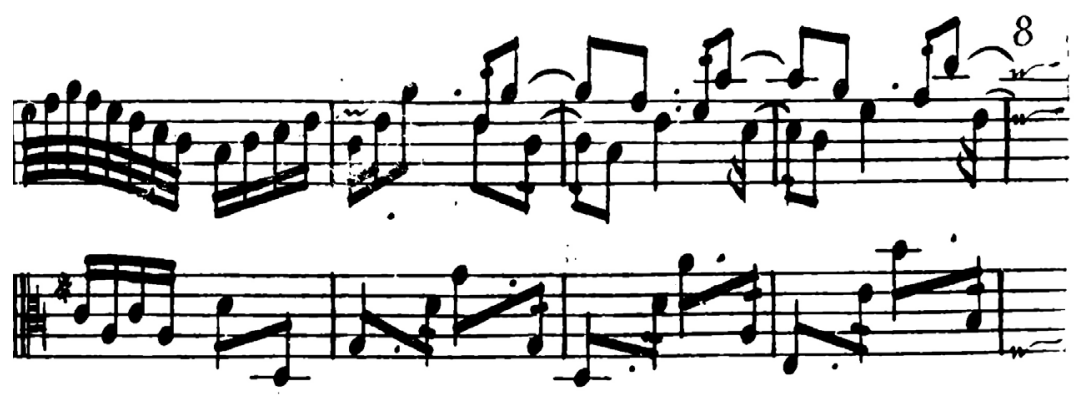


Unless Castel's music for the eyes aimed only at the visual appreciation of flashy colours projected on a wall, it is difficult to argue that they could be aesthetically appreciated as musical discourse; at least not without much cognitive work. Thus, it is open to question to which extent the instrument would be able to successfully communicate the musical intricacies it proposes to signify through colour.

Nonetheless, according to Telemann, music was visually available with the advent of the ocular harpsichord; and that is because for him these specific colours communicate the sound they represent. For the beholder who mastered this language of sounds translated into colours, the beauty of harmony and melody was visually perceivable and recognizable. For Telemann, colour combinations, because they are recurrent and rationally understood, were able to communicate music's features: intervals, chords, dissonances, resolutions, ornaments, etc. In this sense, elements pertaining to counterpoint, such as voice leading patterns, suspensions, different types of imitation, would have been also available to the attentive beholder. Another problem with Telemann's proposition is that this system would require from the deaf 'visual listener' not only a superior level of mastery of the colour codes, but a previous and specialized knowledge of the musical discourse, which would have been an impossibility if the deafness were congenital. It is arguably unlikely that appreciation of music could arise solely from an acquaintance with the music notation of the time and its rules apart from the sonic result they produce. The myriad of resulting shade possibilities inevitably complicates the perceptual process.

However debatable, Father Castel's propositions managed to find their way into the nineteenth-century. Johann Leopold Hoffman's treatise Farbenharmonie from 1786 continued to explore associations between sound and colour, albeit in a less scientific and more artistic way. Two years before Sachs's dissertation, Johann Wolfgang von Goethe publishes his Theory of Colours (1810), where he also proposes connections between colours and tones, thus elaborating on the scientifically rigorous associations broached in Newton's work.

\section{Synthesis}

The Enlightenment yielded mixed readings of sound-colour analogies. On one hand, Castel's experiment and propositions retain the late seventeenth-century idea rooted in natural philosophy that percepts are connected because they are all part of a harmonious world and therefore share qualities when it comes to their essence: their proportions and ratios. Voltaire also acknowledges those connections. Conversely, Locke and Voltaire propose that the senses are subject to experience, and that these analogies cannot take place unless they have been sensually experienced before.

In discussing instances of cross-sensory experience prior to Sachs and his medical coinage of synesthesia, however, one of the main points that Jewanski and Dolan seem to overlook and perhaps fail to recognize is that what is at stake in these eighteenth-century debates is the potential connection between perceived elements themselves. Although synesthesia is generally defined by one inducing perceptual stimulus and a concurrent sensation that is foreign to external reality, this concurrent percept occurs within the perceiver's mind. Having Sachs's 1812 dissertation as a germinal idea, ensuing propositions started suggesting that there may be a connection between sensory percepts that lie in individual synesthetic experience only. In other words, synesthesia takes place in the mind of the perceiver, rather than on arbitrary connections between sensually perceived phenomena such as actual sounds and colours. 
Yet, it is in this eighteenth-century debate that Sachs's (1812) dissertation came into being. His proposition on multisensory experience is not a step forward in the evolution of cross-sensory discussions, especially because it had little to do with it (if anything at all). Rather, it entails a completely new perspective on multisensory experience that previous enlightenment discussions did not at all foresee or premeditate. Besides, the comments on synesthesia in Sachs's dissertation are tangential to his work's priority in describing his own condition: albinism. He says:

Although I am unwilling to speak anything about the minds of our albinos, yet I should nevertheless state some observations concerning colors, which I can attach in no other place, and want to communicate to the reader. (...) There is much which either never comes before the eyes, or which cannot be reckoned with usual sight, that either does not belong to the sense of vision, or which in not perceptible to the senses, which, in the mind of the brother, inspires dark ideas of different colors, so intimate and recurring, that cannot be conceived of, or only scarcely and with difficulty, without a certain attention. (...) The color and the article in which the idea is connected... seem to stand in harmony. (SACHS apud JEWANSKI et al., 2009, p. 297).

Sachs's direct references to music are worth noting as well; he says: "Particularly those things which form a simple series... [such as] the intervals of a musical scale and other similar things, adopt those colors. (...) In addition, others which refer back to no series have their own color... [such as] the timbres of musical instruments" (SACHS apud JEWANSKI et al., 2009, p. 298). Sachs's approach is also original in that it tends towards a more refined characterization of the inducing stimulus. In his dissertation, the trigger for synesthetic experience is no longer limited to the tones in the musical scales, but begin to pertain to other qualities of sound, such as texture and timbre. He also exemplifies his own perception of the musical notes:

The tones in the musical scale depend on the letter with which they are designated, and these relate also to the half-tones, which derive from them. Although the letters $g$ and $b$ actually do not carry a color trace, nevertheless the fifth tone $(g)$ is recognized as green (uncertain) and the first quarter tone $(b)$ is seen quite clearly be the ash gray color. (SACHS apud JEWANSKI et al., 2009, p. 297).

Sachs's first-hand report of his own synesthesia largely differs both from the earlier Enlightenment discussions of sound-colour analogies and the subsequent works by Hoffmann (1786) and Goethe (1810), both of which fall outside the purview of the present essay yet are important works in the historical study of synesthesia.

For the first time in literature, Sachs's colour associations are described as product of the mind. The connection is ultimately found in the perception, not in the perceived. In fact, as a term, synesthesia means a union of the senses, and not a union of the sensorially perceived phenomena. Using the adjective synesthetic in connection to arbitrary associations, for instance, is failing to acknowledge this dichotomy in the approach to tone-colour connections. The following table compares earlier readings of multisensory associations with Sachs's approach in his dissertation (figure 5): 
Fig. 5. Synthesis of Enlightenment debates on multisensory perception and the novel perspective in Sachs's dissertation.

\begin{tabular}{|l|l|}
\hline ENLIGHTENMENT DEBATES (ca.1650-1800) & GEORGE SACHS'S DISSERTATION (1812) \\
\hline $\begin{array}{l}\text { Connections between two or more elements } \\
\text { perceived from the outer world }\end{array}$ & $\begin{array}{l}\text { Connection between a percept from the outer } \\
\text { world and a concurrent sensation taking place } \\
\text { in the mind }\end{array}$ \\
\hline $\begin{array}{l}\text { Connection between two or more actual perceptual } \\
\text { stimuli }\end{array}$ & $\begin{array}{l}\text { Connection between a perceptual stimulus } \\
\text { and a concurrent sensation }\end{array}$ \\
\hline Union of the sensually perceived phenomena & Union of the senses (synesthesia) \\
\hline Multisensory & Synesthetic \\
\hline $\begin{array}{l}\text { Predominantly concerned with pitch(frequency)- } \\
\text { colour relations }\end{array}$ & $\begin{array}{l}\text { Mentions the colour of music intervals, thus } \\
\text { opening the discussion to other properties of } \\
\text { sound }\end{array}$ \\
\hline
\end{tabular}

Synesthesia, as a term, has evolved to denote a specific neurological condition, rather than the arbitrary connections with which philosophers prior to Sachs were concerned. In this sense Castel's harpsichord did not create a synesthetic experience, and indeed could not have created one, for it fostered a priori, arbitrary relationships between sound and colour.

In a brief final consideration, I would like to place the present discussion in the perspective of current research on synesthesia. English psychologist Jamie Ward makes a clear distinction between multisensory and synesthetic perception, arguing that all humans experience a multisensory perception to some extent. We combine information perceived by different senses to understand our surroundings. Associations between sensually distinct elements are also recurrent in language (e.g. "The grass smells so sweet!") But he says that "[although] synesthesia has similarities to multisensory perception," not all multisensory perception is synesthetic. As we have seen, synesthesia is characterized by involuntary, automatic, and consistent associations at a neurological level, instead of by learned associations. Thus, all of the potential cases prior to 1812 that I presented in this study feature, at best, essentially multisensory perceptions and do not align with the innovative reasoning broached by George Sachs. That being said, if these accounts are to be excluded as candidates for synesthesia, it should be due to the fact that they simply fail to qualify according to the standards established in 1812, rather than because they are too "symbolic and metaphorical" to be disentangled, as Jewanski proposed.

\section{Conclusion}

The early nineteenth-century medical discovery of synesthesia seems to have finally met 'scientifically' those cross-sensory relationships extensively discussed, debated, and criticized in Enlightenment philosophy. But its mechanisms are absolutely strange to eighteenth-century thought. Castel's ocular harpsichord, one of the most dramatic attempts in history to achieve in actuality a 'joining of the senses,' simulates synesthetic experience but cannot be identified as such. Yet, its importance when it comes to understanding Enlightenment thought is irrevocable, as it reflects the concerns embedded in the debates taking place at the time.

In this sense, although unplanned, Sachs's dissertation offers a fresh, entirely new, and perhaps still premature approach to cross-sensory associations. It is noteworthy that these fundamental ideas pertaining to synesthesia, as expressed in Sachs account, are still 
valid today, over 200 years later. His account is still considered to be the first scientifically "satisfactory" report on this neurological condition. Nevertheless, the extent to which two centuries of study of synesthesia are absolutely 'scientific' (at least as we understand science today) in approach is still open to question, for some of the properties of Enlightenment discussion still permeate current research.

It is also worth recapitulating that Sachs's propositions came into being in the midst of this 'Enlightened' discussion, and yet had nothing whatsoever to do with it. On the other hand, it is impossible to ignore the significance of eighteenth-century debates exactly because they reflect the philosophical and intellectual background in Sachs's time, and may have to some extent informed his own scientific approach. Sachs's dissertation only becomes ground-breaking in regards to multisensory experiences and synesthesia if contemplated in relation (and in comparison) to the ongoing discussions in which it was immersed historically.

\section{Notes}

1 Grapheme-colour synesthesia is currently defined as an altered perception of graphic symbols, in which letters, numbers and other graphemes elicit synesthetic colour. Grapheme-colour synesthetes, when exposed to an inducing graphic stimulus, will manifest a cross-activation of the brain region responsible for colour processing, thus experiencing a concurrent colour sensation. Some report to 'see' the colour projected onto the grapheme and some to 'see' the colour with their 'mind's eye.' This process is similar in other forms of synesthesia that have colour as a concurrent sensation (e.g. music notation-colour, sound-colour, smell-colour, touch-colour, etc.), although the neural pathways are essentially different for each form.

2 Ward dedicates several portions of his book to a thorough discussion of the characteristics of synesthetic experience. The requirements for a diagnosis of the condition are also available in Cytowic's (2009) Wednesday is Indigo Blue.

3 English translation from the German version available in Jewanski's (2009) chapter on Athanasius Kircher.

4 In Castel's experiment a given note-name is always assigned the same colour: all As are the same colour regardless of the octave in which they are located, and that holds true for all keyboard keys. As the notes go up in octave, however, they become brighter, and as they go down darker. Castel believed all colours stood between black (darkness) and white (light).

5 To represent the seen world with musical sound (or to paint with sound-the very concept criticized in Rousseau's Essay) is not an exclusive aspect of eighteenth-century repertoire. Rather, it is a feature of a wide spectrum of musical compositions throughout history. The very title of the piece used here specifically suggests the singing of birds. In fact, several pieces from this collection evoke extra-musical pictorial elements that occasionally pertain to the sonic world. The most prominent aspect at stake in Enlightenment discussions of multisensory correspondences, however, is the relationship between pitches and specific colour, rather than the idea of painting the visual world with sound.

\section{Bibliography}

ASHER, Julian E.; CARMICHAEL, Duncan A. The Genetics and Inheritance of Synesthesia. In: SIMNER, Julia; HUBBARD, Edward (Eds.). The Oxford Handbook of Synesthesia. Oxford: Oxford University Press, 2013. p. 23-45.

CASTEL, Louis-Bertrand. Clavecin pour les yeux, avec l'art de peindre les sons, et toutes sortes de pièces de musique. Mercure de France, p. 2552-2577, 1725.

CYTOWIC, Richard E.; EAGLEMAN, David M. Wednesday is Indigo Blue: Discovering the Brain of Synesthesia. Cambridge: MIT Press, 2009.

DOLAN, Emily I. The Orchestral Revolution: Haydn and the Technologies of Timbre. New York: Cambridge University Press, 2013.

FRANSSEN, Maarten. The Ocular Harpsichord of Louis-Bertrand Castel: The Science and Aesthetics of an Eighteenth-Century Cause Célèbre. Tractrix, v. 3, p. 15-77, 1991. 
HANKINS, Thomas. The Ocular Harpsichord of Louis-Bertrand Castel; or, the Instrument that Wasn't. Osiris, v. 9, p. 141-156, 1994.

JEWANSKI, Jörg; DAY, Sean A.; WARD, Jamie. A Colourful Albino: The First Documented Case of Synesthesia, by George Tobias Ludwig Sachs in 1812. Journal of the History of the Neurosciences, v. 18, n. 3, p. 293-303, 2009.

JEWANSKI, Jörg. Ist $C=$ Rot?: eine Kultur- und Wissenschaftsgeschichte zum Problem der wechselseitigen Beziehung zwischen Ton und Farbe: von Aristoteles bis Goethe. [Sinzig]: Studio, 1999.

JEWANSKI, Jörg; SIDLER, Natalia; LASZLO, Alexander. Farbe, Licht, Musik: Synästhesie und Farblichtmusik. Bern: Peter Lang, 2006.

JEWANSKI, Jörg; SIDLER, Natalia (Eds.). Synesthesia in the Nineteenth Century: Scientific Origins. In: SIMNER, Julia; HUBBARD, Edward (Eds.). The Oxford Handbook of Synesthesia. Oxford: Oxford University Press, 2013. p. 369-398.

KRÜGER, Johhannes G. De novo musices quo oculi delectantur genere. Miscellanea Berolinensia, v. 7, p. 354,1743 .

NEWTON, Isaac; TURNBULL H. W. Correspondence. Cambridge: Published for the Royal Society at the University Press, 1959.

PIERPAOLI, Diego; ALBANI, Emiliano; DI BENEDETTO, Alessio. Musica ad figuram: il fonocromatismo fra storia, teoria ed arte. Arquata del Tronto (Ascoli Piceno): Museo d'arte immanente, 2000.

ROCH, Eckhard. Chroma - Color - Farbe: Ursprung und Funktion der Farbmetapher in der antiken Musiktheorie. New York: Schott Musikwissenschaft, 2001.

RONDET, M. Lettre écrite de Paris le 17. février 1726 par M. Rondet au R. P. Castel, Jesuite, en résponse au clavecin oculaire. Mercure de France April, p. 650-660, 1726.

STRUNK, Oliver. Source Readings in Music History, Volume 5. New York: Norton, 1965.

VOLTAIRE. The Elements of Sir Isaac Newton's Philosophy. Translated by John Hanna. London: 1738.

WARD, Jamie. The Frog Who Croaked Blue: Synesthesia and the Mixing of the Senses. New York: Routledge, 2008.

Eduardo Sola Chagas Lima: é professor na Burman University (Canadá), doutorando em Educação pela Andrews University (EUA), mestre em Musicologia pela University of Toronto (Canadá), bacharel em violino barroco pelo Koninklijk Conservatorium (Holanda), e bacharel em violino pela Escola de Música e Belas Artes do Paraná. Eduardo atua como pesquisador em diversas áreas de interesse, principalmente Cognição Musical, Sinestesia, e Musicologia Sistemática e Histórica. 